Coertzen, PC

Stellenbosch University

\title{
Religion and the common good in a pluralistic society: Reformed theological perspectives
}

\begin{abstract}
This article is about religion and the common good in a pluralistic society. It is argued with the pluralistic society of South Africa in mind. The theme is further argued against the background of reformed theology and asks about the contribution that reformed theology can make towards the common good in a pluralistic society.

Hierdie artikel is oor die rol van godsdiens in 'n pluralistiese samelewing. Die redenasies vind plaas teen die agtergrond van die Suid-Afrikaanse samelewing. Die beredenering vind ook plaas teen die agtergrond van Gereformeerde teologie en die vraag word gevra watter bydrae Gereformeerde teologie kan maak tot die algemene welsyn in 'n pluralistiese samelewing.
\end{abstract}

\section{THE SOUTH AFRICAN SCENE}

South Africa is indeed a country of many pluralities - there is a plurality of peoples, a plurality of languages, and a plurality of religions as can be seen from the following figures.

\subsection{Plurality of peoples}

Total population: 47,9 million

Black: 38 million (80\%)

White: 4,35 million $(9,1 \%)$

Brown: 4,2 million (8,9\%)

Indian: 1,2 million (2,5\%)

\subsection{Plurality of languages}

\subsubsection{Eleven official languages}

1.2.2 Languages spoken in households:

IsiZulu: $23,8 \%$

IsiXhosa: $17,6 \%$

Afrikaans: $13,3 \%$

Sepedi: 9,4\%

Setswana: $8,2 \%$

English: 8,2\%

Sesotho: $7,9 \%$

Xitsonga: $4,4 \%$

Siswati: $2,7 \%$

Tshivenda: $2,3 \%$

IsiNdebele: $1,6 \%$

Other: $0,5 \%$ 


\subsubsection{English}

Language of

- Trade and Commerce

- Science (?)

- Anchor language of the government?

- Mother tongue speakers: $8,2 \%$

\subsection{Plurality of Religions}

1.3.1 Christianity is the majority religion in South Africa - Christians: 79,8\% (2001 census)

1.3.2 Jewish: $0,2 \%$

1.2.3 Islam: $1,1 \%$

1.2.4 Hinduism: $1,3 \%$

1.2.5 Buddhism: 0,1\%

1.2.6 African indigenous: $12 \%$ of Africa's total population (70 million members)

1.2.7 No religion: $1,2 \%$

\subsection{The position of Christianity}

Within Christianity there is no majority denomination

\subsubsection{Mainstream Churches: $39 \%$}

Reformed: $7,2 \%$

Anglican: $3,8 \%$

Methodist: $7,4 \%$

Lutheran: 2,5\%

Presbyterian: $1,9 \%$

Congregational: $1,4 \%$

Roman Catholic: $8,9 \%$

1.4.2 Pentecostal churches: $7,3 \%$

1.4.3 Other Churches: $12 \%$

1.4.4 African Independent Churches: $40,8 \%$

\section{CLASH OR DIALOGUE AND CO-OPERATION?}

The term "the clash of civilizations" was first used 1990 by Bernard Lewis in an article titled The Roots of Muslim Rage (The Atlantic Monthly, September, 1990). In 1992 Samuel P. Huntington in a lecture at the American Enterprise Institute formulated his theory of a clash of civilizations that he then developed further in an article The Clash of Civilizations? (Foreign Affairs Vol 72, No 3, (Summer, 1993), pp 22-49). In his lecture and article Huntington responded to Francis Fukiyama's book The End of History and the Last Man (1992). In his article Huntington writes, "It is my hypothesis that the fundamental source of conflict in this new world (the world after the Cold War) will not be primarily ideological or primarily economic. The great divisions among humankind and the dominating of source conflict will be cultural. Nation states will remain the most powerful actors in world affairs, but the principle conflicts of global politics will occur between nations and groups of different civilizations. The clash of civilizations will dominate global politics. The fault lines between civilizations will be the battle lines of the future" (Hunitington, 1993:22). About civilization Huntington writes, "A civilization is a cultural entity. Villages, regions, ethnic groups, nationalities, religious groups, all have distinct cultures at different levels of cultural heterogeneity." A civilization is thus the highest cultural grouping of people and the broadest level of cultural identity people have short of that which distinguishes 
humans from other species. It is defined both by common objective elements, such as language, history, religion, customs, institutions, and by the subjective self-identification of people. (Huntington, 1993:24).

Given these characteristics of civilizations and cultures South Africa can clearly be in line for a clash between civilizations. There is for instance the Zulu festival of Ukubuthwa as an typical Zulu cultural festival (le Roux, 2009:13); recently when president Zuma married his third wife and there were outrages against it, he claimed that polygamy was part of the Zulu culture and that he saw nothing wrong with it, he claimed that he had a right to be a polygamist; nowadays when one goes into Absa banks there are pamphlets available for Muslim customers indicating special bank services in accordance with Sha'aria laws (ABSA, Islamic Banking, Banking the Sha'ari'a way, sa). Many more examples can be cited from the different cultures in South Africa. Diverse elements of religious and customary pluralism are indeed present in the South African society. The question is how must Christianity and in fact all religions in South Africa react to this diversity. In response to the theory of the clash of civilizations the former Iranian president Mohammad Khatami introduced the idea of Dialogue Among Civilizations. The term Dialogue among Civilizations became more known after the United Nations adopted a resolution to name the year 2001 as the year of Dialogue among Civilizations. This article is an attempt to contribute to this dialogue and the eventual co-operation between religions in South Africa and at the same time make a contribution form the perspective of Reformed theology.

\section{REFORMED PERSPECTIVES ON PLURALITY}

\subsection{The Kingdom of God}

From a Reformed perspective the Kingdom of God forms the primary context for the whole of creation, individual and society, religion and state. The Dutch theologian, Herman Ridderbos (1978:1), calls the Kingdom of God the most theocentric concept that Scripture offers for our understanding of the creation, humanity, the world and current and future times. God's Kingdom and the Lord Jesus Christ's royal sovereignty comprise the whole of creation. Where Christ's kingship is recognized, something of the Kingdom becomes visible; individuals are liberated, and the entire patterns of their lives are transformed (Ridderbos, 1960:303). Every part of creation forms part of God's Kingdom and, although a specific individual, society or state often does not acknowledge God's sovereignty, it nevertheless, according to a reformed perspective, is and remains a part of the kingdom of God.

\subsection{Plurality}

Plurality is a fact of life in our modern world as can be seen inter alia from the statistical facts about South Africa. This also applies to many, in fact most, societies across the globe.

The Canadian political scientist J L Hiemstra distinguishes a plurality of institutions and associations, a plurality of directions and a plurality of cultural contexts in society (Hiemstra, 2005:21-25). In every society there are pluralities of institutions associations, which are complementary, overlapping and mutually interdependent. This means inter alia that no institution or association is autonomous - a law unto itself - they all exist, or should exist to enable humanity to achieve its true unifying purpose - which for Christians will mean to love God and neighbour. About the plurality of directions Hiemstra writes, "“The full reality of institutional plurality in society can be unfolded in many religious and ideological directions" (Hiemstra, 2005:46). The pluralism of directions that unfolds in a many religious and ideological directions (Hiemstra, 2005,46) is also something very real in many societies. It entails both a confessional and a social element. Confessional pluralism is aimed at entertaining and accommodating a 
diversity of religious expressions and organizations in a community. The social aspect of religious pluralism is aimed at entertaining and accommodating a diversity of social institutions such as churches, synagogues, mosques and other religious associations, families, schools, welfare institutions, academic and civil associations - they all play a very important role in the keeping and expansion of religion. All these religious institutions also play a very important role against the interference of the state in religious affairs; the establishment of religious rights, as well as supplying vital sources for theology, morality, charity, and discipline in society (Witte, 2000:4445).

The fact that Christians cannot accept many of the ideological and religious directions of institutions and associations in society does not mean that they should not be respected and tolerated. Disagreement does not make them less real or diminishes the calling of both religions and the state to deal with the plurality of directions in society-each of course in its own way. "The state must respect and tolerate the convictions and conscience of its neighbours in a plurality of institutions within society while vigilantly executing its limited task of public justice" (Hiemstra, 2005:47). The religions including the church must also respect the convictions of its neighbours in a society with a plurality of other directional individuals, institutions and associations. This does not mean that the church and Christians must approve of all the different directions in society, but it does mean that the church and Christians cannot deny their existence or belittle them. The church must also never forget that it undeniably has the task of proclaiming, through word and deed, the Gospel of the Kingdom of God - calling all people, institutions and associations of whatever direction they may be, to obedience to the Triune God.

Hiemstra also identifies a third kind of diversity namely that which he calls contextual plurality. This refers to the fact that diverse cultures around the world and throughout different historical eras have developed the cultural and social potential of creation in different ways. Hiemstra concedes that some of these developments may be due to the sinful nature of mankind, but more often these unique geographical and historical contextual developments are simply different legitimate responses to God's creation (Hiemstra, 2005:23-24).

\subsection{Freedom of Religion in a pluralistic society}

K. Blei defines freedom of religion in terms of the Universal Declaration of Human Rights (1948). From this he points out that religious freedom has both an individual and a social side. Religious freedom also means more than just having a religion and upholding inner convictions and feelings. Freedom of religion includes the right that everybody can express their religion and faith in worship, teaching, practice, and maintenance. This view of religious freedom means that individuals and religious groups want to live their religion, act according to it, and be witnesses to the truth of their faith, also in public. According to Blei, freedom of religion also relates to the fact that the religious convictions of people usually contain views on how they think society should be organized. He also points out the important fact that freedom of religion implies that the authorities must accept the responsibility and duty to respect and guarantee the right to freedom of religion. This responsibility is not accomplished if the authorities just steer away from an active involvement in religious matters. "It is not just a matter of keeping 'hands off' from religious communities in their territory and leaving them alone. On the contrary, active engagement by the state is required in order to make religious freedom a reality to all religious people. The state should create the possibilities and facilities so that freedom can really be enjoyed and implemented. Otherwise, the principle of religious freedom is in danger of being doomed to remain just a nice principle without significance in practice." (K. Blei, Freedom of Religion: Principle and Practice, http://www.antenna.nl/ikvoud//docs/div/presentation-blei. html; see also L.C. van Drimmelen, sa:199) At the same time, it can also be said that just as the 
state has an active responsibility to guarantee and promote freedom of religion, churches and religious communities have a similar responsibility - they must see to it that their order and structures are adequate for the practice of freedom of religion.

In his attempt to define freedom of religion, Witte claims that "The Essential Rights and Liberties of Religion are (i) freedom of conscience, (ii) the free exercise of religion, (iii) religious pluralism, (iv) religious equality, (v) the separation of church and state, and (vi) the disestablishment of religion by the state (John Witte, 2000:37). These six essential rights and liberties of religion are indeed very handy distinctions to understand what freedom of religion exactly is. As a matter of fact for a country like South Africa with it's plurality of religions within the boundaries of one state they are much needed distinctions on the one hand for the state to know what the essential rights and liberties of religions are vis-à-vis the state but also to empower religions to contribute to the common good of the country.

\subsection{The state and a pluralist society}

Religion apart from its involvement with individuals in society, is also involved with many other social entities for example, marital unions, families, corporations, social institutions, etc. etc. - that which can be called the plurality of associations. However it can be said the state is the most encompassing entity in its own right (Van der Vyver, 2004:35ff), which a religion/church can encounter, in its earthly existence. The state encompasses and co-ordinates, inter-alia by its legislation and policies, all individuals, corporations, and institutions, which include religions, within its sphere of authority.

Christians believe that the state is divinely instituted; in other words, it is an instrument of the sovereignty of the Lord Jesus Christ, or to say it in still other words, the state is the great human representative of Christ's sovereignty over the whole of creation - even if a state itself does not always recognize itself as such. This is also why, with reference to Romans 13:6, many Christians confess that state authorities are God's servants who are executing their God-given command. This conviction brings to the fore a remarkable parallel between church and state in that the centre of the church's existence is simultaneously also the final centre and authority of and over the state - Jesus Christ the Lord!

Apart from being divinely instituted the state is also a historical institution, a human, cultural response to God's call to do justice in the public relations that exist in our lives. Through the course of history the state has taken on many different forms such as kingdoms, principalities, empires, commonwealths, tribal arrangements etc. Sometimes these arrangements were more just and at other times less just. Sometimes they were even straightforwardly unjust, but were always ways of structuring the political life in their times and contexts. In the same way contemporary states are our societies' better or worse answers to God's call to concretely structure political life. This implies that states may be reformed so that they can deal in a more just manner with society (Hiemstra, 2005:39-40).

The state, as embodying a political community, can be characterized by its specific concern, to ensure that people and institutions, directions and contexts are publicly integrated in just ways. The state that has this as its main task is always territorially bound and should function by way of legal rule with the intent to bring about public justice (Hiemstra, 2005:40-46). In other words, such a state will then be obliged to recognize, integrate and protect the plurality of individuals, associations, directions and contexts which fall under its authority. For the church this will mean - as for all other institutions and associations - that the state must allow them the space and the freedom they need to fully respond to their God-given calling. However, should the actions of institutions an associations fail to achieve their essential tasks, or distort the lives of others or harm their members, the state must act to ensure that just public relations exists between all 
and that the common good shared by all societal actors is achieved.

One very important document that deals with the relationship between the state and religions is the constitution of a country. About a constitution Rautenbach and Malherbe (2004:22-23) writes as follows:

"A constitution is a law that contains the most important rules of law in connection with the constitutional system of a country. These include the rules of law dealing with the state, the government bodies of the country, their powers and how they must exercise those powers. In other words, a constitution defines government authority, confers it on particular government institutions, and regulates and limits its exercise. (The exercise of government authority includes the creation of legal rules on virtually every aspect of society.) A constitution guarantees and regulates the rights and freedoms of the individual and determines the relationships that exist between inhabitants of a state and their government bodies. A constitution thus provides a norm against which everybody's actions can be measured and which ensures public stability and security. A constitution is thus a key component of the legal system of a state. In addition, a constitution is regarded in democratic societies as an expression of the will of the people and a reflection of prevailing values, requiring the support of the citizens."

A constitution can also be described as the lex fundamentalis of a country, the basis of its whole legal order. As such it is also regarded as a special law with a higher status than other laws - in fact, all other laws of a country are subject to the constitution and are invalid if they contradict the constitution. A constitution is also accorded supremacy in that it is an entrenched document, i.e. it cannot be amended at will by the government and the government itself is subject to it. To change the constitution certain definite procedures must be followed. Furthermore the courts of the country are assigned the function of enforcing the observance of the provisions of the constitution. In the case of South Africa, Section 2 of the constitution itself stipulates that it is the supreme law of the land, that any law or conduct inconsistent with it is invalid and obligations imposed by it must be fulfilled. Apart from this the South African Constitution is also entrenched and the courts are formally vested with the power to test the constitutional validity of any action by government and declare it invalid if it is in conflict with the constitution:

"All executive authority is also subject to the Constitution. The supremacy of the Constitution therefore obliges government bodies to act consistently with the Constitution, lest their actions be declared invalid by the courts." (Rautenbach \& Malherbe, 2004:25).

Article 36 of the Constitution of South Africa, the so-called "Limitation of rights" clause, enables both the state and any institution of civil society to limit certain rights included in the Bill of Rights on condition that this takes place in accordance with the stipulations of the constitution and prescribes certain procedures according to which rights can be limited in both the state and civil society.

The constitution itself can limit rights internally by means of the constitutional article that entrenches it. It qualifies it (for example article 17-rights may only be exercised peacefully and unarmed) or makes it subject to a further limiting stipulation (for example in the light of article 126[2], the right to freedom of expression guaranteed in article 16 does not allow for the use of so-called "hate-speech"). The constitution also allows for the external limitation of rights by generally applicable legal rules besides specific stipulations contained in the constitution when it:

(i) Is reasonable and justifiable in an open democratic society based on human dignity, equality and freedom, and (ii) satisfies certain proportionality requirements (article 36[1]). 
Institutions of the civil society (such as for example, religious institutions) can thus, by means of the formulation of internal constitutional laws, statutes, church orders, stipulations and regulations, make use of the limitation possibilities that the constitution offers, to interpret or reinterpret each of the stipulations of the Bill of Rights within the context of their own internal constitutions. In the case of churches, this will entail an interpretation or reinterpretation in accordance with the faith identity the church as it is found, inter alia, in the confession(s) of faith and church order of a church. Such a reinterpretation, especially where it pertains to a church's limitation of the rights contained in the Bill of Rights in the light of article 36, must always be very well motivated in the light of the church's faith identity and its resultant church order. Such limitation must furthermore be in compliance with the requirements of article 36 (cf. Du Plessis, 1999:204-206).

\subsection{The Church and Christians in a pluralistic society}

Within the Kingdom of God there are those who are gathered into a unity through the proclamation and acceptance of the gospel. They are gathered into a confessional, cultic, orderly and confessing community - the church (cf. Ridderbos, 1972:296-308). One could say that the church is a community of people who are, and must be, organized in respect of their confession, their worship, their teaching, discipline, pastorate, diaconate, mission, social calling, etc., etc. In all these respects the church is an image of God's Kingdom that simultaneously points to the Kingdom, and it also becomes a place where the Kingdom is revealed and displayed in this world (Heyns, 1977:23-26; Van Ruler, 1978:64).

For the church it is very important that Jesus Christ is its' only Lord and Head. He is the primary subject in his relation to the church, the latter then being the secondary subject. The church must always be about a Christological-ecclesiological relationship (Barth, s.a:678-679). The church is the body of Christ and, as His "fullness."(Ephesians 1:23; Berkhof, 1962,154) This means that it is the area where there should be perfect obedience to Him, the Lord and head (Du Plessis, 1962:76).

Christ rules His church by means of the Word, the Holy Spirit and the ministries/offices that He has given it. This is also a unique characteristic of the church. The proclamation of the Word in a variety of forms, such as preaching, training, charitable deeds, prophetic witness, caring and comforting can also be viewed as the church's unique task, as well as that of the members and the offices in the church. In the Word, the church hears the Lord's voice through the Holy Spirit's Curiological work (Versteeg, 1971:211-213). The church hears the Lord's voice for the time in which it lives, and through the calling and work of the offices and the members of His body, Christ cares for His body. The offices must equip, feed, discipline, stimulate and co-ordinate the members of the body for their task within the church, but also within God's greater Kingdom. The offices must also join and lead the body to be able to function as the body of Christ in the world (Roberts, 1963:140). All of this will mean inter alia that the church must continuously assist its members to walk with God in righteousness - also with regard to the political challenges that they face. The church must help its members to distinguish between the plurality of religious and ideological directions that confront them every day and what they have to do to remain loyal to Christ. It is also the task of the church to help its members to understand the societal context in which they live, be it that they are a majority or a minority religion; what the consequences are when a state that does not allow any religion in the public sphere or when a state guarantees freedom of religion to all religions within its borders and what the impact of that is on churches. It is also the task of the church as an institution but also through its individual members, which it has to equip for this task, to witness to the Kingdom of God and the sovereign rule of Jesus Christ before the political powers of the day. This can be done through prayer, dialogue or the prophetic 
witness of the church, as well as through the examples of righteous living by the members of the church (Hiemstra, 2005:11-12).

The faith identity of a specific church denomination usually finds its expression in the confession(s) of faith and the resulting church order of that church. A confession(s) of faith is a very fundamental document for any church. It is a systemized expression of what the specific faith community understands as the main truths of the Bible. As such the confession(s) of faith is always subject to the teaching of the Bible. Until it is changed the confession of faith determines the faith identity of a church. The church order or constitution of a church contains the rules that govern a church's life and actions at a given point in time. The primary sources for a church order are the Bible and the confession(s) of faith of the church. Secondary sources are the history of the church and the tradition in which it stands. Although the historical-traditional or contemporary context of a church can never be a normative source for it's the faith identity or the church order, it is something, which a church must always take into account. In the end a church must always weigh up its faith identity against the Word of God and the needs of the time. It is usually in this area where church, state and society must have clarity on their different identities and functions. The church order of a church usually states what the confession(s) of faith is to which the church adheres; what the offices are allowed for in the church, what their authority each office holds, how the office bearers are elected; and how the church assemblies are called and what authority they have. The church order also lays down the rules for the training of its office bearers; the requirements for eligibility for offices; the conditions of employment for ministers and other employees of the church. Furthermore the church order contains the definitions of the functions of the church; the rules of discipline and conflict resolution in the church as well as the rules that govern the church's relationships with respect to the state and society and their institutions, as well as relationships with other churches and religions. Very important is the fact that a church order contains the rules that have to be adhered to during the assemblies of the church; this means that the church order will also contain rules regarding the entrenchment of the confession of faith of the church. The church order has authority within the church and the courts of the country also recognize this authority and, although the authority of a church order can be amended, it can only be done according to prescribed means. It can be said that a church order is a contemporary expression of the identity of a church within the context in which it is called to function. As such it is a very important document in the relationship between church and state (see Coertzen, 2004:150; 187-209).

All of the above does not necessarily mean that the state, in its relation to the church, views the church as the church sees itself (Barth, s.a:686). It often happens that the state does not take the existence of the church seriously; or it propagates an absolute separation between the state and the church and the church is relegated to the so-called inner or private sphere of life. It can also happen that the state sees the church as a mere subject of itself that has to abide by its rules, denying the church its unique existence as part of the Kingdom of God. For the church the danger always exists that it can begin to view itself in the same way as the state often does, namely as a mere voluntary association of people, albeit then a voluntary association with a special relationship to the Person whom they call Christ. It can happen that while the state sees the church as a mere voluntary association of people that performs certain actions in the Name of Christ, the church can also begin to see itself as such and loose view of its very special religious identity and calling. The church may never accept or be reconciled to such view of itself. The law of the state - the ius circa sacra - may never, without responsible theological reflection by the church, become the law in the church - the ius in sacra. Given the freedom of religion in a democratic society, the church is obliged to do everything possible to convince the state to view and judge it as it expresses itself in its obedience to the Word of God and as this is expressed in 
its confession of faith and in its church order. This also places the church under the obligation to express itself in its church order in a way that is consistent with its confession(s) of faith and faith convictions. In other words, the church must use the space that constitutional freedom of religion allows it to define itself in a way consistent with its faith identity as a faith community and not wait for or allow the courts of the country or the laws of the country to define it.

\subsection{On the relationship between the state and religion}

In the history of the relationship between church and state two big trends can be distinguished, a distinction which proves to be very valuable. On the one hand the so-called Constantinian model, and on the other hand the so-called Theocratic model which was advocated in stronger or weaker terms by the medieval church (Hiemstra, 2005:29). Constantinian and Theocratic models of the relationship between church and state are not unique to Christianity. Both these models can also be found in other religions and the way in which they see their relationship with the state and the rest of society.

Both the Constantinian and Theocratic models are positive about the role that religion should play in society - according to many Christian thinkers that support of these models, society should serve the Triune God and Christianity should provide direction to society. The models differ on who should be the guide or the leader of the role that religion plays in society. According to the Constantinian model political authorities are dominant and above church authorities. This means that they often assist, influence and sometimes fully control and use the church/religion. It also means that the state has a role to play in the advancement and protection of the "true religion" even to the extent that it may use its coercive power. Right in our own day we detect signs of Constatinianism in the relationship between religion and state when we hear that a political party wants to guide the debate on morality in the South African society, using religions in the process. According to the Theocratic model church and religious authorities determine the role of religion in society - the church (or religion) should dominate political authorities as well as the rest of society (Hiemstra, 2005:28-29).

In the history of South Africa the Constantian model has played a significant role right from 1652 up until 1994. After 1994 South Africa became a Constitutional state in which the Constitution of the country with guaranteed freedom of religion became the guiding rule for the relationship between religions and the state. The condition for this relationship is that the state must really take up its role to guarantee, promote and protect freedom of religion while religions must take up the challenge to use freedom of religion to fulfil their religious role and to serve the common good of the country.

\subsection{The nature of a Christian contribution to the dialogue and co-operation.}

Because Christians are called to seek justice (Amos 5:15,24) one can argue that they are also called to political involvement, as well as involvement in society. The belief that God's redemption is at work in this present world is one of the reasons why Christians ought to engage in political activity. According to reformed theology Christians must bring Christ's renewing influence to bear on public life, furthering the cause of God's Kingdom in this world in obedience to Scripture. In a country like South Africa this will of necessity entail both dialogue and co-operation with other religions and cultures. As a matter of fact the makeup of the pluralistic South African society offers a unique opportunity for dialogue and co-operation between the religions in our country for the sake of the good of all the citizens of the land and as a witness to the common grace of God. As to the nature of Christian involvement the following characteristics can be mentioned 


\subsubsection{Modesty}

Christians must always be cautious to claim that they speak for the Lord. Smidt quotes Skillen "We must constantly act with an attitude of true humility. We should undertake every civic duty, every political action - we can add every dialogue and co-operation - with the avowed understanding that they are not God's will but only our response to God's will. The attitude of humility will lead us to be modest and self critical in our claims and stated intentions." (Smidt, 2007:147). A True understanding of freedom of religion ought to keep Christians from an uncompromising claim that they alone have the answers to the problems of the land and nobody else can make any meaningful contribution. At the same time Christians must witness to the fact that they have a very important contribution to make.

\subsubsection{Tolerance}

Tolerance is a second important characteristic of a Christian contribution to dialogue and cooperation. Tolerance does not mean indifference or relativism. Genuine toleration calls for peaceful co-existence despite the fact that there are areas where real disagreement exists. Forbearance/ tolerance means permitting the other with whom we disagree to exist and, when appropriate to persuade and engage others by word. In the present age, prior to the full establishment of the kingdom of God that will be fully inaugurated with the second coming of Christ, we must exercise genuine tolerance - an action that defends both truth and co-existence.

\subsubsection{Dialogue and co-operation}

In a pluralistic country like South Africa people that share the same kind of values due to their religious convictions need to engage in dialogue and co-operation in the matters that concern all of us; they also need to co-operate with each other in order to articulate and find that which is the best for the country and all its citizens -, the elderly as well as the children, blue collars as well as white collars, single persons as well as married couples and families, government as well as subjects (Smidt,2007:147-149).

\subsection{Charter of religious rights and freedoms as part of the dialogue and cooperation}

3.8.1 Clear distinction must be made between the freedom of religion that every human being possess as a quality of life and freedom of religion of religion as something guaranteed by the constitution of a country. Although there are examples in history of efforts by governments to give citizens a certain amount of freedom to practice their religion, like the Edict of Milan (315?), the Magna Charta (1214), the Edict of Turda (1568) and the Edict of Nantes (1598) it was really only after the Second World War that international charters of rights were accepted to protect freedom of religion. In this regard there is art 18 of the Universal Declaration of Human Rights (10 December 1948); art 18 of the International Convention of Civil and Political Rights (16 December 1966) (Malherbe, 2007,Motivation art 6; Lerner, 1996:86,91); art 9 of the European Convention for the Protection of Human Rights and Fundamental Freedoms (Rome 1950/1953) (Malherbe, 2007,Motivering, art 6; Gunn, 1996:305). Furthermore there is also the African Charter for Human and Peoples' Rights and the Declaration on the Elimination of all Forms of Intolerance and Discrimination Based on Religion or Belief (1981) and the Declaration on the Rights of Persons Belonging to National or Ethnic Religious and Linguistic Minorities (1992) (Malherbe, 2007, Motivering art 6).

3.8.2 For Christians the deepest foundation for freedom is that God created man in His image with the capability to choose for and serve God. Man lost this freedom when he chose to follow the way of evil instead of the way of God. In Jesus Christ the freedom of those who believe in 
Him was restored. This is a freedom that is not dependent on any constitutional guarantee. This is one reason why Christianity could endure through many centuries and many regimes without having a constitutionally guaranteed right to freedom of religion. Where there is a constitutional guarantee for freedom of religion it enhances the freedom that Christians have in Christ and offers Christians the opportunity to publicly proclaim their faith identity in Christ without any fear of prosecution or discrimination.

3.8.3 Freedom of religion as a constitutional right is difficult to put into a mere definition. It is much more a concept that needs to be circumscribed. It is also a concept that can continue to develop in future. The South African Constitution describes freedom of religion in rather vague terms merely as "... the right to freedom of conscience, religion, thought, belief and opinion"(Constitution art 15 (1)). It further states that "... religious observances may be conducted at state or state aided institutions" given that it complies with certain conditions (Const art 15 (2)) Article 15 (3) provides for “... marriages conducted under any tradition, or a system of religious, personal or family law." Primarily it is and remains the task of the religions and religious people of South Africa to identify their religious rights in a way consistent with their own religious identity and within the ambit that the Constitution and the laws of the country allow. If the religions and religious people of South Africa do not accept this task it will be taken over by government, the courts of the country and society and it will be fulfilled in a way, which will not necessarily further freedom of religion - a way that can again work Constantinianism in hand. In fulfilling their task churches and religions must make very sure of their deepest roots and identity and also make sure of the rights and obligations that spring from those roots and identity. They must also take note of the Charter of Human Rights contained in the second chapter of the Constitution as well as of the acts of Parliament, which further describe the content, and application of the rights concerned. "The following examples of such acts may be mentioned:

- Section 9 (the right to equality): the Promotion of Equality and Prevention of Unfair

Discrimination Act, Act 4 of 2000

- Section 23 (labour rights): the Labour Relations Act, Act 66 of 1995

- Section 32 (the right to access to information): the Promotion of Access to Information Act, Act 2 of 2000

- Section 33 (the right to administrative justice): the Promotion of Administrative Justice Act, Act 3 of 2000

Directly or indirectly, numerous other acts give effect to the rights in the Constitution as well, as in the case of health, housing, education, the environment, the rights of children, the right to vote, and the rights of accused persons and prisoners" (Malherbe, 2007,Motivation art 4). Religions need to position themselves with regard to the rights in the Constitution and acts that describe the content and application of those rights in a responsible manner in order to determine whether they can subscribe to them as a religion or to avail themselves of the grounds on which they may want to limit those rights in their organization.

3.8.4 Charter of Religious Rights for South Africa is currently being developed and will be put as a proposal to a public conference to be held on 21 October 2010 In the proposed Charter the following religious rights and freedoms are identified - the rights and freedoms are merely mentioned without going into all the subdivisions. The references are to the articles in the proposed Charter of Religious Rights for South Africa.

- The right to believe or not to believe (art $1-2.3$ )

- The obligations of the state with regard to religious rights (art 3-3.2, art 9.3) 
- The right to observe and exercise one's religion (art 4-4.4)

- The right to education consistent with ones religious convictions (art 7 and 8).

- The right to maintain particular matrimonial, family and personal legal traditions (art 5)

- The right to institutional freedom (art 9)

- The rights and obligations of religion with regard to the laws of the land (art 9.4, 10).

- The right of religion to freedom of expression (art 6-6.3).

- The right of religion to freedom of association (art 1-2.2)

- The right of religion to freedom of propagation (art 6.2).

- The right to religious dignity (art 6.3).

- The right of religion to solicit, receive, manage and spend voluntary financial and other forms of support and contributions.

- The right of religion to conduct upliftment and charity work in the community and to establish maintain and contribute to charity and welfare associations, and solicit, manage, distribute and spend funds for this purpose.

All of the above in fact describes what the freedom of religion entails and to which churches and religions in South Africa can lay claim as religious rights and freedoms.

\section{CONCLUSION}

South Africa is indeed a country of many pluralities - cultural and religious. This in itself contains the possibility of a clash of cultures. This article argued that we must not try and deny these pluralities or force them to become one. To the contrary the pluralities must be accepted and granted their lawful space under the Constitution to live and work - as long as it is within the laws of the land.

A second argument of this paper was that the plurality of religions in SA need not clash but can serve the common good of the land through their dialogue and co-operation in drafting a Charter of Religious Rights and Freedoms for South Africa as well as through the endorsement of such a Charter and then taking it to Parliament for enactment - something which the Constitution allows for (Constitution article 234). Already in 1990 Judge Albie Sachs wrote "Ideally in South Africa, all religious organisations and persons concerned with the study of religion would get together and draft a charter of religious rights and responsibilities ... it would be up to the participants themselves to define what they consider to be their fundamental rights." (Albie Sachs, 1990:46+47). A Charter of Religious Rights and Freedoms for South Africa as a document that recognizes the fact of religious pluralism in SA is a starting point, which will help both religions and their adherents to understand what their rights and freedoms are. At the same time it will help the state to know what the rights of religions are in SA and what it's own limits are. Through the dialogue and co-operation of religions in this regard the common good of the country and its citizens will be served.

\section{BIBLIOGRAPHY}

ABSA, Islamic Banking, Banking the Shari'a way, sa

Barth, K. s.a. Church Dogmatics,vol IV, part 2. Edinburgh: T \& T Clark.

Berkhof, H, 1962, Tweërlei Ekklesiologie. In: Kerk en Theologie,nr 13.

Blei, K. Freedom of religion: Principle and Practice. Online at http://antenna.nl/ikvoud//docs/div/ presentation-blei.html.

Coertzen, P. 2004. Decently and in Order. A Theological reflection on the Order for, and the Order in, the Church. Leuven: Peeters. 
Du Plessis, I J. 1962. Christus as Hoof van Kerk en Kosmos. Proefskrif, Kampen.

Gunn, T, Jeremy. 1996. "Adjudicating Rights of Conscience Under the European Convention on Human Rights." In Van der Vyver, Johan D.\& Witte, John Jr (eds.)

Religious Human Rights in Global Perspective. Legal Perspectives. The Hague, Boston, London: Martinus Nijhoff Publishers, 305-330.

Heyns, J A. 1977, Die Kerk. NG Kerkboekhandel, Pretoria.

Hiemstra, John, L. 2005. "Church, State and the Kingdom of God, an Overview." In: REC FOCUS. Quaterly Journal from the REC COMMISSIONS, vol 5, (Number 2, June 2005), pp 3-49.

Huntington, Samuel P. 1993. "The Clash of Civilizations?", Foreign Affairs Vol 72, (No. 3, Summer), pp. 2249.

Le Roux, A. 2009. Afrika veroordeel Zoeloe-ritueel. Die Burger, 30 September 2009, 13.

Lerner, Natan. 1996. Religious Human Rights Under the United Nations. Van der Vyver, Johan D.\& Witte, John Jr (eds.). Religious Human Rights in Global Perspective. Legal Perspectives. The Hague, Boston, London: Martinus Nijhoff Publishers, pp 79-134.

Malherbe, E.F.J. 2007. Motivation for the South African Charter of Religious Rights and Freedoms. Copy available at pc@sun.ac.za

Rautenbach, I.M. \& Malherbe, E.F.J. 2009. Staatsreg. Johannesburg: Lexis Nexis.

Ridderbos, H. 1960. Commentaar op het Nieuwe Testament: Kolossenzen. Kampen:J H Kok.

Ridderbos, H. 1972. De Komst van het Koninkrijk: Jesus' prediking volgens de Synoptische Evangeliën. Kampen:J H Kok.

Ridderbos, H. 1978. Studies in Scripture and its authority. Grand Rapids:Eerdmans.

Roberts, J H. 1963. Die Opbou van die Kerk volgens die Efese-brief. Groningen: VRB.

Sachs, A. 1990. Protecting Human Rights in a New South Africa. Contemporary South African Debates. Cape Town: Oxford University Press.

South African Charter of Religious Rights and Freedoms as proposed on 13 October 2009. Copy available at pc@sun.ac.za

Smidt, Corwin. 2007. The Principled Pluralist Perspective. In Kemeny, P.C. (ed.) Church, State and Public Justice. Five Views. Downers Grove, Illinois: IVP Academic, pp 391-403.

Van der Vyver, J J. 2004. Leuven Lectures on Religious Institutions, Religious Communities and Rights. Leuven: Peeters.

Van Drimmelen, L.C. s.a. "Kerk en Staat”. In Van 't Spijker, W \& Van Drimmelen, L C. s.a. Inleiding tot de Studie van het Kerkrecht. Kampen: J.H. Kok. pp 194-206.

Van Ruler,AA., 1987. Verwachting en Voltooiing. Nijkerk: G F Callenbach.

Versteeg, J. 1971. Christus en de Geest: Een exegetisch onderzoek naar de verhouding van de opgestane Christus en de Geest van God volgens de brieven van Paulus. Kampen: J H Kok.

Witte, John. 2000. Religion and the American Constitutional Experiment. Essential Rights and Liberties. Boulder: Westview.

\section{KEY WORDS}

Religion

Common Good

Pluralistic Societies

Reformed

Theological perspectives

\section{TREFWOORDE}

Godsdiens

Algemene welsyn

Pluralistiese samelewing

Gereformeerd

Teologiese perspektiewe

\section{P Coertzen}

Research Associate

Faculty of Theology

Stellenbosch University

pc@sun.ac.za 